\section{HENRY BENEDICT MEDLICOTT, M.A., F.R.S.}

Bors August 3, 1829.

Mr. Medicotr was the second son of the Rev. Samuel Medlicott, Rector of Loughrea. co. Galway, and was born in that parish. He was educated at Trinity College, Dublin, and in 1851 he was appointed to the Geological Survey in Ireland. In 1853 he was transferred to the English branch of the Geological Survey, and worked until the close of the year with Aveline in the Vale of Pewsey and other parts of Wiltshire. Late in the same year he was appointed on the staff of the Indian Geological Survey, and commenced duties in 1854. During that year he was also chosen Professor of Geology at the Thomason College of Engineering at Roorkee. Mr. Medlicott became Superintendent (and afterwards Director) of the Geological Survey of India in 1876, and served in that capacity until he retired in 1887. His geological work related almost wholly to India and is published in the Memoirs and Records of the Geological Survey of that country.

In conjunction with Dr. W. T. Blanford he brought out in 1879 the well-known "Manual of the Geology of India," which summarized all that was known of the country at that date. Otherwise his published works are not numerous. He communicated in 1867 to the Geological Society of London a paper on "The Alps and the Himalayas : a Geological Comparison" (Quart. Journ. Geol. Soc., vol. xxiv, pp. 34-52). He was author also of a work entitled "Evolution of Mind in Man," 1892.

In 1888, shortly after his retirement from the public service, he was awarded the Wollaston Medal by the Council of the Geological Society. From this date he resided for the most part at Olifton, near Bristol, where he died at the age of 76 .

\title{
MISCFIIAINEOUS.
}

Torquay Natural Hrstory Soointy.-Mr. Alexander Somervail, the Curator of the Torquay Natural History Society, reports that the following important addition has been made to the Museum by Mr. J. G. Hamling, F.G.S., of The Close, Barnstaple, who has presented his valuable collection of Devonian and Culm fossils of North Devon to the Society's Museum. The collection consists of about a thousand specimens illustrative of these two geological formations. It is in North Devon where the Devonian formation is fully developed, its upper portion being almost absent in the South. The upper division consists of the Pickwell, Baggy, and Pilton groups, each characterised by its own distinctive fossil remains. The Culm (or Carboniferous) formation is also more fully represented in North Devon, and its fossils are more numerous and varied. The whole collection will prove a most valuable acquisition. 